\title{
Nasionalism: Character Education Orientation in Learning Development
}

\author{
Dian Arief Pradana ${ }^{1}$, Mahfud $^{2}$, Candra Hermawan ${ }^{3}$, Herdiana Dyah Susanti $^{4}$ \\ 1,2,3 Faculty of Teacher Training and Education, Universitas 17 Agustus 1945, Banyuwangi, Indonesia \\ ${ }^{4}$ Faculty of Engineering, University of 17 Agustus 1945, Banyuwangi, Indonesia \\ dianariefpradana.dap@gmail.com
}

\begin{abstract}
The values of nationalism can be learned from educational materials that are oriented towards character development. Character education is part of a revolutionary zone among students, therefore character education is a very important part to be urgently developed in the minds of the student head because students are the next generation who will lead the nation and state. Character learning that is oriented towards the values of nationalism can overcome various social problems. Building character for the current generation is one of the goals of national education. The Ministry of National Education (2011) describes the matter of character building through educational institutions that in the implementation process designing students to have caring care and responsibility. This analysis concerns that character education is part of the formation of identity, selfconcept, self-esteem, psychology, personality, character, individualistic behavior, character and character. This writing method uses a descriptive method. Discussion: 1). Zone of Nationalism and Learning. 2). Character Education and Learning Development. Conclusion: Character learning in universities is one of the development of learning which should provide an effective space in internalizing the values of Nationalism in shaping the character and civilization of the Indonesian nation to students.
\end{abstract}

Keywords

nationalism character education; learning development

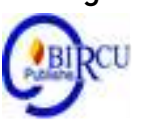

\section{Introduction}

Since the last decade, the character of education has become an important issue. This problem is caused by the emergence of components of the nation's behavior phenomenon, especially the younger generation who tend to prioritize hedonistic traits that are not in accordance with the religious principles of social principles, legal rules and norms that apply in Indonesian society (Sudrajat, 2011). In the context of nationality, this behavior shows the fading values of the national spirit among the younger generation which are increasingly evident. The act of not paying attention to the national symbol, not memorizing Pancasila, disliking and even not knowing the national anthem, not recognizing national heroes, not being proud and not knowing the nation's culture, would be even worse.

This phenomenon should not be allowed to drag on. A relatively quick and precise solution must be sought immediately. Education is a very important human need because education has a duty to prepare Human Resources (HR) for the development of the nation and state. Human resources as labor or employees play an important role in improving productivity and achievement of predetermined objectives (Ningsih, 2018). In 2010, finally 
a formal solution was made by the government by issuing a policy on cultural education and national character (Suharjono, 2012). In the grand design of national culture and character education, it is stated that the strategic places to carry out character education are educational institutions or schools.

Actualization of the application of character values in learning in the learning environment, the role of the teacher is very vital and strategic. It is called vital because, in the education process in schools, the teacher becomes a central figure, resource person and role model in an effort to recognize, understand and habituate the application of character values. It is called strategic because the duties and responsibilities make the intensity of teacher interaction with students very high. Daily teachers can meet and become the main focus of students in the class (Rohendi, 2016).

Furthermore, to meet the interactional needs in the learning process the teacher must know and understand the character education development procedures that are neatly arranged in the semester learning plan. So that in its application and inculcation of character values it will be easy to read with the cognitive psychomotor and affective aspects that have indicators of assessment. Then must understand the background, objectives, and content of character education policies. According to Astuti et al (2019) Education is an obligation of every human being that must be pursued to hold responsibilities and try to produce progress in knowledge and experience for the lives of every individual. In addition, teachers must also be able to integrate the values contained in character education into learning and skills in conveying the values of character education in classroom learning practices. Integrating these character values can be done in all subjects in an educational environment (Wening, 2012a).

One of the learning models to develop nationalism is to use a character education model. This learning model is portfolio-based and, through this model, students are invited to conventionally understand scientific principles but they can also develop their ability to work together through empirical practice of learning activities. Therefore, the learning process becomes more challenging, active and meaningful (Riyanto, 2017). Learning is associated with the mental development of students who cannot be separated from their activities. Therefore, the mental development of students depends on the extent to which students manipulate tools and other learning tools (Suparno, 2009). Mental development is not a plan of a separate piece of information.

The construction of a frame of mind built by the teacher in character learning is part of the process of introducing the community environment experienced by students so that the learning process is combined with the socio-cultural of the local community or the cultural environment of the local community which has been used as the basis for cultural values, so that students can explore himself according to the culture experienced (Nishimura, 1995). The learning is aimed at reconstructing students who are looking for information and finding out knowledge that is able to solve problems, cooperate, and tolerate diversity. If the desire is successful in a satisfying way, it will increase students' self-confidence as well as a high sense of responsibility and civilized humans who can identify themselves with stable, independent personalities and have emotional stability with intellectual knowledge. They are also able to control themselves consistently, which is also called Emotional Quotient (Damanhuri et al., 2016).

The values of nationalism can be learned from educational materials that are oriented towards character development. Character education is part of the revolution zone among students, therefore character education is a very important part to be urgently developed in the minds of the head of students because students are the next generation who will lead the nation and state. If the ideals of the nation become a special orientation in the future, 
then the function of character education must read the direction of the nation's interests, the process of building knowledge of youth or student skills in the present is the creation of a national character that is oriented to the zone of nationalism. When learning and education development is oriented to the values of nationalism it will indirectly activate self-esteem the special character possessed by every Indonesian society (Siswoyo, 2013).

\section{Research Methods}

Method uses descriptive. The descriptive method according to Sugiono (2009) is descriptive research is research that functions to sharply narrate and analyze narratives that develop in a scientific context that is oriented to data or samples that have been classified as they are without analyzing and making public conclusions with the intention of Another that descriptive analysis research takes problems or focuses attention on problems as they are when the research is carried out, the results of the research which are then processed and analyzed are given turn points to draw conclusions.

\section{Discussion}

\subsection{Zone of Nationalism and Education}

Indonesian Nationalism Develops in three broad areas. First is the growth of nationalist sentiment among elite groups, the second is the Islamic movement led by the modernist movement, the third is the rise of left-wing groups in Indonesia (Nusarastriya, 2015). Eriksen uses Ernest Gellner's definition of the concept of nationalism. Ernest Gellner describes nationalism as follows "Nationalism is a political principle which claims that cultural diversity is the main relationship between people in society". Various principles of authority that may exist among civil society, this legitimacy leads to the fact that group members today have the same culture. The strongest integration of the process is the need for cultural equality which is a requirement and sufficient for legitimate affiliation in matters of nationalism (Eriksen, 2014).

Furthermore, Eriksen explains the definition of Gellner's opinion; "Nationalism, in short, is a zone of political revolution in which the interests of change do not cross the boundaries of social interests". Eriksen believed that the state should consist of political boundaries and not ethnic boundaries between the rulers and other states. The term nationalism is related to ethnicity and state (Harris, 2016). According to the MerriamWebster Dictionary, nationalism is defined as "loyalty and devotion to a nation, especially a sense of national consciousness," and "exalting a nation above personal interests and placing major emphasis on cultural identity and its interests as a means of struggle against convention together or supranational groups (Merriam-Webster, 2013). Nationalism in value is much highlighted which can have a positive effect on the state and nationality, therefore nationalism is needed in value seeing nationalism studies appearing in the mid19th century, especially in Indonesia (Kusumawardani, 2004).

Talking about values in Indonesian nationalism has a variety of inherited values related to the character in terms of values and these values must be maintained in the current era appears during the learning process. Because the "educational development paradigm" is a "meaning-making process" that helps us define analysis, use present learning structures to inform future action and consider the real implications of thinking. It is an interconnected and transformative relationship between thinking and action (Dewey, 1916). Hopefully this can be used as an inspiration to think about the attitude of nationalism in the present. 
Without the development of innovative learning, or only with experience (conventional) can cause us to "reinforce stereotypes and offer simple solutions to complex problems and inaccurately generalized based on limited descriptions "(Ash \& Clayton, 2009). Involves the development of learning in intellectual studies, helps us articulate information sources, confronts bias, and examines causal relationships, critical evaluation and knowledge transfer (Ash \& Clayton, 2009). ). Indicators of the value of nationalism become objects of learning development for the purpose of forming meaning and character building. The sociological theory of the Indonesian nation provides us with a historical narrative that our nation has a spirit of nationalism that is different from other nations, our spirit of nationalism is formed due to exploitation by colonial or colonial nations so that our nationalism is formed on the basis of unity and unity and the same fate in struggle. The character of our nationalism is against oppression in any form, it is clear that our nationalism orientation is an orientation of human values.

The Value in question is a value that upholds the dignity of Indonesian people and is part of the thesis of Indonesian nationalism thought as well as the fundamental foundation for the founding of Pancasila. (Silaban, 2012), The argument states that nationalism is part of the social concept and the concept of integration which results in an effect of unity and integrity, therefore youth, especially students, should understand the concept of complete nationalism without infiltration rather than foreign concepts developed in text narratives. academically, character education should be more observant to see that our nationalism interests are not only limited to sectoral and primordialism egos but rather humanities (Miftahuddin, 2018), in this context students must defend human values which in turn become a spirit of nationalism among participants students in the archipelago who are used as arguments for the struggle to face the challenges of the times. Of course, contemporary struggles have encountered a lot of conflicts, because their birth is always side by side with the negative interests of democracy (actors democracy) actions) (Democracy, 2014), therefore the development of learning is needed in order to foster a spirit of character in all interests, of course in this case the context of the value of nationalism which is value required. Therefore education must guarantee the formation of national cadres who have a nationalist character.

\subsection{Character Education and Learning Development}

Character building is part of the national education system in National education regulation number 20 of 2003 which explains that education is a conscious effort in structurally creating a learning atmosphere and learning process so that students actively develop and explore themselves so that they have basic characters that relies on the religious power of self-control, personality, intelligence, noble character and social skills for him, of course this also focuses on the interests of the nation and state society. The goal of national education integration is education based on Pancasila and the 1945 Constitution which is based on cultural and religious life and is sensitive to demands of changing times.

This is the government's response in overcoming it. The government has reissued Presidential Regulation No. 87 of 2017, affirming that the goal of strengthening character building is to shape students to be good, moral and of good character. Presidential Decree number 87 of 2017 has been issued by the President of the Republic of Indonesia regarding Strengthening Character Education in hopes of being able to overcome the problems faced by the current generation. This apprehensive condition requires solutions both at the internal and external levels regarding character building, so that special support is needed for the community and educators in training the character of students (Hadisi, 2015). 
The Ministry of National Education (2011) describes the matter of character building through educational institutions that in the process of implementing it, students design care and responsibility, or what is commonly called self-esteem. Self-esteem is the most important part of the formation of individual character.Coopersmith (1967) argues that self-esteem is part of values that provide self-evaluation decisions and habits in the context of deciding all kinds of social problems, especially in the process of accepting rejection and social indications and processes. Seek confidence in his abilities and meaning and his own success. Therefore, it must provide a special frame for the individual which then becomes a personal judgment related to feelings of worth or meaning that are in the expression of the individual's daily attitude and automatically when we analyze deeply self-esteem forms a high sense of social responsibility towards him..(Bortolan 2018). Selfesteem provides a special space that individuals have a tendency to evaluate themselves related to their needs in daily life behavior, self-esteem can shape individuals to assess themselves as individuals who have meaningful abilities and character competences, it is a part that is formed on the basis of individual assessment of his ideal (Royzah, 2016). The development of nationalism value-based learning will provide a response stimulus to the formation of characters who have high self-esteem, therefore learning in the learning environment when put forward using a nationalism value orientation will form a character of youth or students who have a national spirit and are aware of the interests of humanity (Bortolan, 2018).

The development of character education in this context based on the values of nationalism is part of the fulfillment of National Education specifically designed to galvanize individual characters based on religious, cultural and personality values so that innovation rather than learning development using nationalist values will automatically present indicators nationalism indicators that are packaged in the semester learning design. When this is implemented, it will automatically bring out characters who have high selfesteem and when the individual has a high ice cream taste, he will be able to evaluate himself and filter the needs of his own social behavior because self-esteem provides predictive solutions or decisions. Individuals in facing the problems that exist in themselves are then able to filter out the globalization of effects and modernization of effects that are developing in the present era, the need for self-esteem in character is the most important part in forming students, because this education will confirm and strengthen the belief system. Individuals from all mature considerations, this information provides a new concept of the individual's perspective in overcoming himself and motivating himself (Thomas et al., 2018)

Self-esteem cannot be formed by itself without any combination with the presence of $\mathrm{s}$ There is a growing socioculturalism of students or youth and components of educational institutions that fully support character programs, so that character building based on the values of nationalism must be inputted into two components of society and components of educational institutions. The culmination of the goal of character planting in the learning development process is the fulfillment of the ability to think, the ability to assess, choose and decide social problems faced by individuals, self-esteem can provide an answer in the first two schemes, namely the individual's belief to carry out his mental, which is usually called Self-efficacy, the second is the individual's ability to understand the reality and facts that occur in their life needs or commonly referred to as Self-reliance (Fitra, 2015).

The individual belief system will provide a special accentuation for solving social problems and automatically it will confirm and reinforce careful considerations (Kelley, 1979). Information and the environment or socioculturalism in the context of society provides a conceptual view of how to think and understand the reality of society's reality in 
everyday life and provides a positive social interaction in the process of self-internalization where in the community, students usually recognize how to tolerate culture, how to understand the existence of laws. Community law and ways of thinking that are influenced by local culture (Thomas et al., 2018). Therefore, the needs related to character in the individual body will provide a different space in the process of identity because it is influenced by several components that have been mentioned above. Information and the environment provide a new perspective on the concept of individuals in constructing selfmotivation and the ability for positive social interaction in the process of selfinternalization. The process of self-internalization in the formation of self-considerations as a social Self is influenced by three interrelated aspects. First, Self-concept is a description of what people perceive about themselves. Second, self-esteem is an affective component of Self, the third is Self-presentation, which is a manifestation of behavior Self. (Gray, 1997). The social self that will be presented in this article is an in-depth explanation of self-esteem.

The mental process that is formed because the system rather than self-esteem itself has actually provided a special alternative related to character formation. The mental process that is expected in the process of developing educational learning provides a gap in the formation of characters who have a complete national spirit, the process can actually be passed in a society that has a positive socio-culture or commonly known as Local Wisdom so that students or youth actually have a self-concept that has been created by environment, character education actually only delivers to remind and reconstruct values that need to be developed to answer the challenges of the times. Nationalism is only a system of value ideas whose relevance must be maintained in the present and is a character of national identity that every Indonesian individual must possess, of course, a high nationalism spirit automatically is a high national character that has a spirit of self-esteem towards humanitarian orientation so that the hope is students are able to detect that the interests of nationalism are part of the interests of humanity, this needs to be clarified. Even emphasized in the concept of developing education teaching (Kawamichi et al., 2018).

Branden (1994) said that if someone faces a deficiency in efficacy, it self-is very risky, because this person wants to be attached to what he understands and experiences difficulty in adjusting to new demands or situations. Self-respect, is belief in self-values; positive behavior that leads to a sense of belonging and feeling happy; feeling secure in producing well-desires, thoughts, and needs; feeling that happiness is a basic right for him. People who have self-respect want to feel that their life is meaningful, have a belief that their life and existence can help others, feel that they are good, useful, worthy of respect, and worthy to fight for their personal rights to achieve success and fulfillment.

The main source of making self-esteem has an internal character, meaning that it depends on people's own actions, not on what other people live, in reality, making selfesteem is inseparable from external aspects, namely citizens. For Egan (1976 in Kelley, 1979), people perceive themselves through feedback from others as well as from observations of the consequences of their actions. In line with the maturity process, family, friends, and residents in general also instill prevailing values and norms so that people want to be judged based on these norms. People learn to evaluate themselves with the results of all interactions and experiences that are woven into them. Acceptance of the community area of the individual personally affects self-esteem.

The process of perceiving experience occurs simultaneously with the process of interpreting and assessing the environment. Unconsciously, personal experiences that have been perceived by individuals in the past will influence them to assess, view, and determine their existence. Experiences that are perceived as positive or pleasant 
experiences will make individuals tend to see themselves as competent in facing life's challenges, which in turn will form self-efficacy in individuals (Hornsey et al., 2018). Selfrespect is formed when individuals are treated respectfully by others in their environment, have high and satisfying experiences of interacting with others, so that individuals feel confident that they are useful and meaningful to others.

The purpose of good teaching should not only highlight the attainment of theoretical and instant knowledge, but also share meaningful learning outcomes and positive transformations in student behavior. As one of the key components in the teaching and learning process in schools, a teacher certainly plays a central position and contribution in the learning process. Regarding this learning development is a pedagogical application that promotes a set of personality / character values. For that it takes a variety of efforts for these learning objectives. Increasing the meaning of character learning for students is focused on efforts that can be tried by all teachers in making learning designs, in directing learning, one must also review some of the challenges experienced in society. So that it can be an emotional appreciation or also called a generator that affects the way individuals think and live emotions (Poole et al., 2018).

Character learning education can help students overcome social problems. Teaching and learning methods that encourage ethical and responsible individual development by teaching them about good values that must be demonstrated and applied in society, teaching a person the values of caring for others, honesty, responsibility, and other important traits which makes citizens who have an identity. Such characters in the context of self-esteem can be encouraged from a positive environment so that they have a significant impact on students. Character education will be useful for social harmony when they are involved and interact with other people in society. (Branden, 1994). This means that individuals will strive to find symbols that can provide positive experiences and good environmental acceptance. Indicators in the achievement of formation self-esteem are part of the values in character building because that is why character formation requires increasing self-esteem studentin the learning process. So that this will be a synergy of common goals in history learning which carries the mission of forming student character. The solution is learning must be oriented to the value of self-esteem in the formation of a spirit of nationalism (Wening, 2012b). Learning development with character-oriented (selfesteem), will automatically internalize the values of nationalism.

\section{Conclusion}

Character learning in universities is one of the development of learning which should be the main pillar in orientation and inculcating the values of Nationalism in shaping the character and civilization of the Indonesian nation to students. There are many opinions that education when it is oriented in a character frame will facilitate the implementation of the values of nationalism. The zone of character education and learning development is very strategic to increase the spirit of nationalism of students. This learning helps students to better understand the values contained in nationalism as well as fostering character attitudes that have a national spirit. 


\section{References}

Astuti, R.W., Waluyo, H.J., and Rohmadi, M. (2019). Character Education Values in Animation Movie of Nussa and Rarra. Budapest International Research and Critics Institute-Journal (BIRCI-Journal). P. 215-219.

Bortolan, A. (2018) 'Self-Esteem And Ethics: A Phenomenological View', Hypatia, 33(1), Pp. 56-72. Doi: 10.1111/Hypa.12388.

Damanhuri, D. Et Al. (2016) 'Implementasi Nilai-Nilai Pancasila Sebagai Upaya Pembangunan Karakter Bangsa', Untirta Civic Education Journal.

Democracy (2014) 'Democracy In Brief', Igarss 2014, (1), Pp. 1-5. Doi: 10.1007/S13398014-0173-7.2.

Dewey, J. (1916) 'Experience And Thinking', In Democracy And Education. Doi: $10.2307 / 2178611$.

Eriksen, T. H. (2014) 'After The Nation? Critical Reflections On Nationalism And Postnationalism', Journal Of Multilingual And Multicultural Development. Doi: 10.1080/01434632.2014.973289.

Fitra, R. (2015) 'Hubungan Harga Diri Mahasiswa Dengan Kemampuan Aktualisasi Diri Dalam Proses Belajar Metode Seven Jump Di Pogram Studi Ilmu Keperawatan Uin Syarif Hidayatullah Jakarta', Fakultas Kedokteran Dan Ilmu Kesehatan.

Gray, A. (1997). Indigenous Rights And Development: Self-Determination In An Amazonian Community, Oxford: Berghahn Books. Grubb.

aHadisi, L. (2015) 'Pendidikan Karakter Pada Anak Usia Dini', Al-Ta'dib.

Harris, E. (2016) ‘Why Has Nationalism Not Run Its Course?', Nations And Nationalism. Doi: 10.1111/Nana.12185.

Hornsey, M. J. Et Al. (2018) 'A Microscopic Dot On A Microscopic Dot: Self-Esteem Buffers The Negative Effects Of Exposure To The Enormity Of The Universe', Journal Of Experimental Social Psychology, 76(February), Pp. 198-207. Doi: 10.1016/J.Jesp.2018.02.009.

Kawamichi, H. Et Al. (2018) 'Neural Correlates Underlying Change In State Self-Esteem', Scientific Reports, 8(1), Pp. 1-14. Doi: 10.1038/S41598-018-20074-0.

Kelley, H.H. (1979). Attribution Theory In Social Psychology, Lincoln: University Of. Nebraska Press.

Kusumawardani, A. Dan F. (2004) 'Nasionalisme', Buletin Psikologi, Tahun Xii, No. 2, Desember 200461.

Merriam-Webster (2013) Merriam-Webster Dictionary, Merriam-Webster Dictionary.

Miftahuddin, M.- (2018) 'Nasionalisme Indonesia: Nasionalisme Pancasila', Mozaik: Jurnal Ilmu-Ilmu Sosial Dan Humaniora. Doi: 10.21831/Moz.V4i1.4386.

Ningsih, S. (2018). The Relationship Between Motivation and Worker's Productivity in Civil Registration and Population Department, Asahan Regency, Indonesia. Budapest International Research and Critics Institute-Journal (BIRCI-Journal). P. 148-160.

Nishimura, S. (1995) 'The Development Of Pancasila Moral Education In Indonesia', Southeast Asian Studies.

Nusarastriya, Y. (2015) 'Sejarah Nasionalisme Dunia Dan Indonesia', Pax Humana.

Poole, K. L. Et Al. (2018) 'Trajectories Of Self-Esteem In Extremely Low Birth Weight Survivors Through Adulthood', Journal Of Applied Developmental Psychology. Elsevier, 56(February), Pp. 35-41. Doi: 10.1016/J.Appdev.2018.02.003.

Riyanto, A. (2017) 'Pancasila Dasar Negara Indonesia', Jurnal Hukum \& Pembangunan. Doi: 10.21143/Jhp.Vol 37.No 3.151. 
Rohendi, E. (2016) 'Pendidikan Karakter Di Sekolah', Eduhumaniora | Jurnal Pendidikan Dasar Kampus Cibiru. Doi: 10.17509/Eh.V3i1.2795.

Royzah (2016) Artikel Pendidikan Karakter.Pdf, Pdf Pendidikan.

Silaban, W. (2012) 'Pemikiran Soekarno Tentang Nasionalisme', Jurnal Dinamika Politik, 1(3), Pp. 1-6. Available At: Https://Jurnal.Usu.Ac.Id/Index.Php/Dpol/Article/Download/1034/581.

Siswoyo, D. (2013) 'Pandangan Bung Karno Tentang Pancasila Dan Pendidikan', Jurnal Cakrawala Pendidikan. Doi: 10.21831/Cp.V5i1.1264.

Sudrajat, A. (2011) 'Mengapa Pendidikan Karakter?', Pendidikan Karakter. Doi: 10.21831/Jpk.V1i1.1316.

Suharjono, M. (2012) 'Filosofi Nilai Dalam Pendidikan Karakter', Jurnal Pelopor Pendidikan.

Thomas, E. C. Et Al. (2018) 'Beck Self-Esteem Scale-Short Form: Development And Psychometric Evaluation Of A Scale For The Assessment Of Self-Concept In Schizophrenia', Psychiatry Research. Elsevier Ireland Ltd, 263(October 2017), Pp. 173-180. Doi: Https://Doi.Org/10.1016/J.Psychres.2018.02.053.

Wening, S. (2012a) 'Pembentukan Karakter Bangsa Melalui Pendidikan Nilai', Jurnal Pendidikan Karakter. Doi: 10.21831/Jpk.V0i1.1452.

Wening, S. (2012b) 'Pembentukan Karekter Bangsa Melalui Pendidikan Nilai', Jurnal Pendidikan Karakter, Ii(1), Pp. 55-66. Doi: 10.21831/Jpk.V0i1.1452. 